\title{
Penerapan Model Pembelajaran Snowball Throwing dalam Meningkatkan Hasil Belajar Peserta Didik Mata Pembelajaran Pendidikan Agama Islam di SMPN 23 Konawe Selatan
}

\author{
Sufiani \\ Institut Agama Islam Negeri Kendari \\ Email : sufiani1969@gmail.com \\ Aris Try Andreas Putra \\ Institut Agama Islam Negeri Kendari \\ Email : aristryandreasputraaritonda@gmail.com
}

\begin{abstract}
Abstrak
Penelitian ini bertujuan untuk mendeskripsikan penerapan model pembelajaran snowball throwing dalam meningkatkan hasil belajar peserta didik mata pelajaran pendidikan agama Islam pada kelas VIII 2 di SMP Negeri 23 Konawe Selatan. Jenis penelitian ini adalah penelitian tindakan kelas (PTK) dengan prosedur penelitian dalam dua siklus dengan beberapa tahapan yaitu perencanaan, tindakan, pengamatan dan refleksi. Teknik pengumpulan data yang digunakan yaitu observasi, tes hasil belajar dan dokumentasi. Observasi dilakukan untuk mengetahui aktivitas peneliti dan peserta didik dalam pelaksanaan pembelajaran. Tes hasil belajar dilaksanakan untuk menentukan ketuntasan hasil belajar peserta didik. Sedangkan dokumentasi digunakan untuk untuk mendapatkan data tentang keadaan dan jumlah peserta didik yang akan diteliti pada kelas VIII 2 SMP Negeri 23 Konawe Selatan. Dari hasil penelitian maka peserta didik yang memperoleh nilai 70 ke atas pada tes awal pra siklus yakni 5 orang dengan rata-rata 59,14 dengan persentase sebesar $23,80 \%$. Setelah pelaksanaan siklus I, peserta didik yang mencapai ketuntasan belajar di atas nilai 70 sejumlah 11 orang dengan nilai rata-rata 63,80 dan persentase 52,38\%. Selanjutnya setelah pelaksanaan siklus II, siswa yang memperoleh nilai 70 ke atas berjumlah 17 orang dengan rata-rata 71,90 dan persentase $80,95 \%$.
\end{abstract}

Kata Kunci : Snowball Throwing, Hasil Belajar, Pendidikan Agama Islam.

\begin{abstract}
This study aims to describe the application of the snowball throwing learning model in improving the learning outcomes of students in Islamic religious education subjects in class VIII 2 at SMP Negeri 23 Konawe Selatan. This type of research is a classroom action research (PTK) with research procedures in two cycles with several stages, namely planning, action, observation and reflection. The data collection techniques used were observation, test learning outcomes and documentation. Observations were made to determine the activities of researchers and students in implementing learning. Learning outcome tests are carried out to determine the completeness of student learning outcomes. Meanwhile, documentation is used to obtain data about the state or number of students who will be studied in class VIII 2 SMP Negeri 23 Konawe Selatan. From the results of the study, students who scored above 70 in the pre-cycle initial test were 5 people with an average of 59.14 and a percentage of 23, 80\%. After the implementation of cycle I, 11
\end{abstract}


students who achieved mastery learning above a value of 70 with an average score of 63.80 and a percentage of $52.38 \%$. Furthermore, after the implementation of cycle II, 17 students who obtained $a$ value of 70 and above with an average of 71.90 and a percentage of $80.95 \%$.

Keywords: Snowball Throwing, Learning Outcomes, Islamic Religious Education.

\section{PENDAHULUAN}

Pendidikan memegang peranan yang sangat penting untuk menciptakan sumber daya manusia yang berkualitas dan bermutu, termasuk pendidikan yang diselenggarakan di sekolah. Pendidikan yang diselenggarakan di sekolah, keberhasilannya banyak ditentukan dalam proses pembelajaran yakni keterpaduan kegiatan yang dilakukan oleh guru dan peserta didik dalam proses pembelajaran. Upaya tersebut diselenggarakan dalam berbagai jenjang dan jenis pendidikan untuk mencapai tujuan pendidikan nasional.

Tujuan pendidikan nasional yang dirumuskan dalam Undang-Undang Nomor 20 Tahun 2003 yaitu berkembangnya potensi peserta didik agar menjadi manusia yang beriman dan bertakwa kepada Tuhan Yang Maha Esa, berakhlak mulia, sehat, berilmu, cakap, kreatif, mandiri dan menjadi warga negara yang demokratis dan bertanggung jawab. Tujuan pendidikan tersebut harus difahami oleh mereka yang terlibat dalam perancang dan perumus pengembangan kurikulum sehingga apa yang dirancang dan dirumuskan harus bermuara pada pengembangan potensi peserta didik agar menjadi manusia yang beriman dan bertakwa kepada Tuhan Yang Maha Esa, memiliki akhlak mulia, sehat, berilmu, cakap dan lain sebagainya.

Untuk mengembangkan potensi peserta didik sebagaimana yang tercantum dalam Undang-Undang Nomor 20 Tahun 2003, maka peran guru dalam perbaikan mutu dan kualitas pendidikan menjadi sangat penting. Guru harus berupaya meningkatkan kualitas pembelajaran yang dilakukan di sekolah. Berkaitan dengan hal tersebut, Hamalik berpendapat bahwa melalui peningkatan kualitas pembelajaran, peserta didik termotivasi untuk belajar, daya kreativitasnya akan meningkat, semakin positif sikapnya, semakin bertambah jenis pengetahuan dan keterampilannya dan semakin mantap pemahamannya terhadap materi pelajaran.

Sejalan dengan pendapat tersebut di atas, Sanjaya mengemukakan pula bahwa usaha guru dalam rangka mengembangkan kreativitas belajar peserta didik menjadi salah satu penentu utama bagi keberhasilan dalam pelaksanaan pembelajaran. Salah satu usaha yang dilaksanakan oleh guru adalah merencanakan dan menerapkan strategi atau model pembelajaran agar tujuan pendidikan dapat tercapai.

Model pembelajaran merupakan salah satu komponen yang harus direncanakan sebelum guru melaksanakan proses pembelajaran. Guru dituntut untuk menentukan strategi dan model pembelajaran sebelum pembelajaran dilaksanakan.

Sementara Kurniasih mengemukakan bahwa pembelajaran merupakan suatu proses yang memerlukan penerapan model atau strategi pemelajaran.

Berkaitan dengan beberapa teori di atas, maka penjabaran dari model pembelajaran harus direncanakan lalu diaplikasikan dalam pelaksanaan pembelajaran sehingga terjadi interaksi yang baik antara guru dan peserta didik maupun sesama peserta didik.

Bertolak dari beberapa teori di atas, ternyata yang terjadi tidak demikian. Terdapat sebagian guru masih menggunakan strategi dan model pembelajaran konvensional sehingga tidak terjadi interaksi yang baik antara guru dan peserta didik maupun sesama peserta didik dalam proses pembelajaran. Dengan demikian peserta didik merasa jenuh dan bosan dalam mengikuti kegiatan pembelajaran dan pada akhirnya hasil belajar peserta didik menjadi rendah. Untuk mengatasi masalah tersebut, maka guru harus memilih strategi dan model pembelajaran yang tepat sesuai dengan 
karakteristik peserta didik dan karakteristik mata pelajaran. Salah satu model pembelajaran yang dimaksud adalah snowball throwing. Model pembelajaran snowball throwing adalah model pembelajaran yang dapat menggali potensi peserta didik dalam membuat dan menjawab pertanyaan melalui sebuah permainan imajinatif dengan membentuk dan melempar bola salju yang terbuat dari kertas. Bola salju berisi pertanyaan yang dibuat oleh peserta didik kemudian dilempar kepada perserta didk yang lain untuk dijawab.

Sementara Tri Setiawati berpendapat bahwa snowball throwing sebagai salah satu model pembelajaran aktif yang pada hakekatnya mengarahkan atensi peserta didik terhadap materi pembelajaran.

Penelitian ini diawali dengan kegiatan observasi pada tanggal 15 Februari 2020 yaitu melakukan pertemuan dengan Kepala Sekolah dan guru mata pelajaran pendidikan agama Islam di SMP Negeri 23 Konawe Selatan. Pada pertemuan tersebut peneliti melakukan wawancara bebas dengan guru mata pelajaran pendidikan agama Islam untuk mengetahui lebih jelas kondisi pelaksanaan pembelajaran dan hasil belajar mata pelajaran pendidikan agama Islam. Dari hasil observasi awal tersebut, diketahui bahwa hasil belajar peserta didik masih rendah karena dalam proses pembelajaran guru belum menerapkan model pembelajaran yang bervariasi yang dapat membangkitkan semangat peserta didik sehingga peserta didik tidak termotivasi dalam mengikuti proses pembelajaran.

Dalam kegiatan observasi awal tersebut, peneliti pula menemukan data perolehan nilai awal sebelum penerapan model pembelajaran snowball throwing. Peserta didik yang mendapat nilai 70 ke atas dengan kategori tuntas yakni sebanyak 5 orang dan peserta didik yang mendapat nilai 70 ke bawah dengan kategori tidak tuntas sebanyak 16 orang. Secara keseluruhan peserta didik nilai rataratanya yakni 59, 14 dan persentase $23,80 \%$. Hal tersebut menunjukkan bahwa penguasaan peserta didik terhadap materi pembelajaran belum tuntas. Guru belum menciptakan suasana pembelajaran yang menyenangkan, peran guru masih dominan sehingga peserta didik cenderung bosan dan jenuh dalam mengikuti proses pembelajaran. Oleh karena itu peneliti pula langsung membicarakan rencana waktu pelaksanaan tindakan yang akan diterapkan baik pada siklus I maupun siklus II.

Berdasarkan beberapa teori di atas dan observasi awal oleh peneliti, maka peneliti ingin mengadakan penelitian yakni "Penerapan Model Pembelajaran Snowball Throwing dalam Meningkatkan Hasil Belajar Peserta Didik Mata Pelajaran Pendidikan Agama Islam di SMP Negeri 23 Konawe Selatan".

\section{METODE PENELITIAN}

Penelitian ini dilaksanakan pada kelas VIII 2 di SMPN Negeri 23 Konawe Selatan semester genap tahun pelajaran 2019/2020 dengan jumlah peserta didik sebanyak 21 orang yakni 9 orang laki-laki dan 12 orang perempuan. Jenis penelitian ini adalah penelitian tindakan kelas yang model dan desainnya mengacu pada teori yang dikemukakan oleh Arikunto yakni kegiatan penelitian yang dilakukan terhadap subyek yang menjadi sasaran (peserta didik) untuk memperbaiki situasi pembelajaran di kelas agar terjadi peningkatan kualitas dalam pelaksanaan pembelajaran. Adapun desainnya dapat digambarkan sebagai berikut :

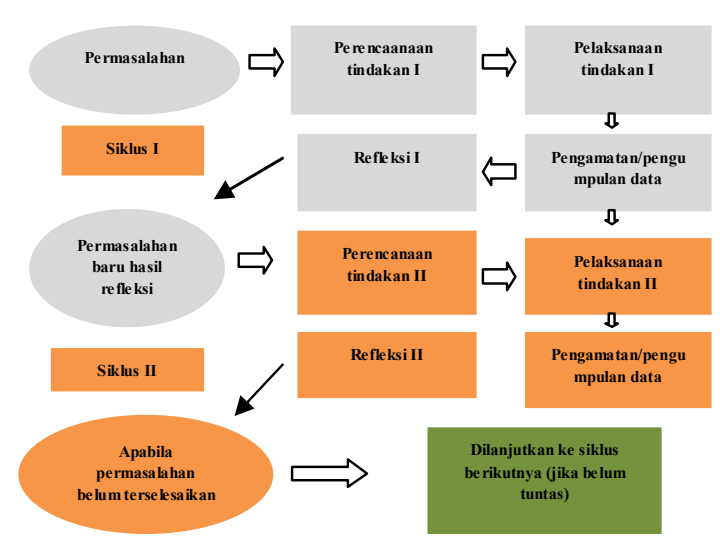

Gambar 1. Desain Penelitian Tindakan Kelas (Suharsimi Arikunto, 2015). 
Senada dengan pendapat di atas, Kunandar dalam Ekawana mengemukakan bahwa penilitian tindakan kelas merupakan suatu kegiatan yang dilakukan oleh guru atau bersama-sama orang lain (observer/kolaborator) yang bertujuan untuk memperbaiki dan meningkatkan mutu proses pembelajaran di kelas. ${ }^{9}$ Penelitian tindakan kelas berdasarkan ciri khasnya yaitu adanya tindakan-tindakan tertentu untuk memperbaiki proses pelaksanaan pembelajaran di kelas. Menurut prosedur penelitian tindakan kelas, maka penelitian ini dilaksanakan dalam bentuk siklus yang terdiri dari empat tahap yaitu : perencanaan (planning), tindakan (action), pengamatan (observing), dan refleksi (reflecting). Materi yang dibahas pada penelitian tindakan kelas dalam penelitian ini adalah Dendam dan Munafiq.

Prosedur penelitian tindakan kelas ini dilaksanakan dalam dua siklus di mana setiap siklus terdiri dari dua kali pertemuan dan dilaksanakan sesuai dengan kompetensi yang ingin dicapai dalam pembelajaran. Sistematika pelaksanaannya baik pada siklus I maupun siklus II adalah perencanaan yakni menyusun rencana pelaksanaan tindakan selama pelaksanaan penelitian. Jenis kegiatan yang dilakukan dalam perencanaan yaitu membuat rencana pelaksanaan pembelajaran, menyiapkan alat dan bahan ajar yaitu materi ajar dan kertas berbentuk bola, menyiapkan lembar observasi untuk aktivitas peneliti dan peserta didik, membuat LKS berupa soal yang akan dikerjakan bersama sesuai dengan tujuan pembelajaran serta implikasi tindakan. Tahapan selanjutnya adalah tindakan yakni penerapan model pembelajaran snowball throwing dalam pelaksanaan pembelajaran yang dilakukan dalam dua siklus yakni apabila pada tindakan pertama tidak berhasil sesuai dengan tujuan pembelajaran yang telah ditetapkan maka akan dilakukan tindakan pada siklus II dengan mengikuti tahapan-tahapan sebagaimana yang dilakukan pada siklus I.

Kemudian dilanjutkan dengan pengamatan yaitu suatu kegiatan terhadap keseluruhan proses pembelajaran pendidikan agama Islam yang berlangsung di kelas VIII 2 SMP Negeri 23 Konawe Selatan. Proses terakhir dari tahapan penelitian tindakan kelas adalah refleksi. Refleksi dilakukan untuk menganalisis hasil tindakan agar dapat diperbaiki pada tindakan berikutnya.

Teknik pengumpulan data dalam penelitian ini adalah observasi, tes hasil belajar peserta didik dan dokumentasi. Teknik observasi digunakan untuk mengumpulkan data-data secara langsung yang dilakukan oleh guru mata pelajaran pendidikan agama Islam dan seorang peneliti lainnya sebagai observer untuk menilai aktivitas peneliti dan peserta didik selama proses pembelajaran berlangsung. Tes hasil belajar peneliti gunakan untuk mengukur hasil belajar, pengetahuan dan kemampuan yang dimiliki oleh peserta didik baik secara individu maupun kelompok. Sedangkan dokumentasi digunakan untuk mendapatkan data tentang keadaan atau jumlah peserta didik yang diteliti pada kelas VIII 2 SMP Negeri 23 Konawe Selatan.

Indikator keberhasilan kinerja merupakan rumusan kinerja yang akan dijadikan acuan atau tolak ukur dalam menentukan keefektifan penelitian tindakan kelas. Indikator kinerja pada penelitian ini yaitu apabila $80 \%$ jumlah peserta didik di kelas telah memperoleh nilai 70, maka dikatakan berhasil, jika sebaliknya peserta didik di kelas yang memperoleh nilai 70 di bawah $80 \%$, maka dapat dikatakan belum berhasil dan akan dilanjutkan pada tahap selanjutnya sampai indikator keberhasilan mencapai $80 \%$. Kriteria ketuntasan minimal (KKM) yang telah ditetapkan oleh sekolah mata pelajaran pendidikan agama Islam adalah 70 .

\section{HASIL DAN PEMBAHASAN Tindakan Siklus I}

Pada tindakan siklus I terdiri dari beberapa tahapan sebagai berikut :

\section{Perencanaan Tindakan}

Tahap perencanaan pada siklus I yaitu menyusun rencana tindakan yang dilakukan selama siklus I sesuai dengan model pembelajaran snowball throwing dengan 
materi pokoknya yakni Dendam. Tindakan siklus I dilaksanakan dalam 2 kali pertemuan yakni tanggal 22 Februari 2020 dan 29 Februari 2020 sesuai roster pelajaran di SMP Negeri 23 Konawe Selatan. Adapun tahapan persiapan rencana tindakan pada sikuls I yaitu : 1) peneliti membuat silabus dan rencana pelaksanaan pembelajaran (RPP) dengan menggunakan langkah-langkah model pembelajaran snowball throwing sesuai dengan materi pokok pada setiap siklus, 2) mempersiapkan materi pokok serta media pembelajaran berupa kertas seperti bola salju, 3) mempersiapkan lembar observasi aktivitas guru dan peserta didik, 4) membuat lembar kerja siswa (LKS) berupa soal-soal yang akan diberikan kepada peserta didik , 5) membuat soal evaluasi yang akan diberikan pada setiap akhir siklus.

\section{Pelaksanaan Tindakan Siklus I Pertemuan Pertama ( Sabtu, 22 Februari 2020)}

Pertemuan pertama siklus I dengan materi pokok tentang Dendam. Peneliti melakukan pembelajaran berdasarkan langkah-langkah yang terdapat dalam rencana pelaksanaan pembelajaran (RPP).

Kegiatan awal pembelajaran dimulai dengan ucapan salam, berdo'a, absensi, memberi motivasi, menyampaikan materi yang akan dibahas, menyampaikan tujuan pembelajaran dan melakukan apersepsi.

Pada kegiatan inti, peneliti membentuk kelompok dan masing-masing ketua kelompok memberikan penjelasan materi, kemudian masing-masing ketua kelompok kembali ke kelompoknya untuk menjelaskan materi pembelajaran kepada teman kelompoknya. Setelah itu masing-masing peserta didik diberikan satu lembar kertas kerja untuk menuliskan satu pertanyaan yang menyangkut materi yang telah dijelaskan oleh ketua kelompok. Selanjutnya kertas tersebut dibuat seperti bola dan dilempar dari satu peserta didik ke peserta didik yang lain selama kurang lebih 5 menit. Setelah peserta didik dapat satu bola atau satu pertanyaan maka diberikan kesempatan kepada peserta didik untuk menjawab pertanyaan yang tertulis dalam kertas berbentuk bola salju tersebut secara bergantian. Setelah semuanya mendapat giliran, kemudian peneliti menyimpulkan materi pembelajaran.

Sedangkan pada kegiatan penutup, peneliti melakukan evaluasi dengan memberikan LKS kepada peserta didik. Peneliti pula memberikan pesan moral dan menutup pembelajaran dengan ucapan hamdallah secara bersama-sama.

Pelaksanaan Tindakan Siklus I Pertemuan Kedua (Sabtu, 29 Februari 2020)

Pertemuan ke dua siklus I dengan materi pokok tentang Dendam. Kegiatan pembelajaran pada pertemuan ke dua siklus I ini sama halnya dengan pertemuan pertama siklus I.

Kegiatan awal pembelajaran dimulai dengan ucapan salam, berdo'a, absensi, memberi motivasi, menyampaikan materi yang akan dibahas, menyampaikan tujuan pembelajaran dan melakukan apersepsi.

Pada kegiatan inti, peneliti membentuk kelompok dan masing-masing ketua kelompok memberikan penjelasan materi, kemudian masing-masing ketua kelompok kembali ke kelompoknya untuk menjelaskan materi pembelajaran kepada teman kelompoknya. Setelah itu masing-masing peserta didik diberikan satu lembar kertas kerja untuk menuliskan satu pertanyaan yang menyangkut materi yang telah dijelaskan oleh ketua kelompok. Selanjutnya kertas tersebut dibuat seperti bola salju dan dilempar dari satu peserta didik ke peserta didik yang lain selama kurang lebih 5 menit. Setelah peserta didik dapat satu bola atau satu pertanyaan maka diberikan kesempatan kepada peserta didik untuk menjawab pertanyaan yang tertulis dalam kertas berbentuk bola tersebut secara bergantian. Setelah semuanya mendapat giliran, kemudian peneliti menyimpulkan materi pembelajaran.

Sedangkan pada kegiatan penutup, peneliti melakukan evaluasi dengan memberikan LKS kepada peserta didik. Peneliti pula memberikan pesan moral dan menutup pembelajaran dengan ucapan hamdallah secara bersama-sama. 


\section{Observasi}

Observasi dilaksanakan untuk mengamati pelaksanaan tindakan pembelajaran di kelas sesuai dengan model pembelajaran snowball throwing. Aspek-aspek yang diamati dalam kegiatan observasi meliputi aktivitas peneliti dan peserta didik selama pelaksanaan proses pembelajaran. Observasi ini dilakukan oleh observer yakni guru mata pelajaran dan peneliti lainnya sejak tindakan dimulai yakni dari awal berlangsungnya proses pembelajaran sampai berakhirnya pelaksanaan pembelajaran dengan menggunakan lembar observasi aktivitas guru dan peserta didik.

\section{Hasil Observasi Aktivitas Peneliti Pada Siklus I Pertemuan Pertama}

Observer yang dimaksud dalam penelitian ini adalah anggota resmi dari kelompok yang bertugas mengamati dan terlibat penuh dalam kegiatan penelitian sekaligus menjadi pengarah agar dalam penelitian sesuai dengan skenario peneliti untuk mendapatkan data yang akurat. Tugas observer dalam penelitian ini adalah melakukan pengamatan terhadap proses pembelajaran pendidikan agama Islam melalui model pembelajaran snowball throwing. Pengamatan tersebut menggunakan lembar observasi aktivitas peneliti untuk mengetahui kesesuaian antara rencana tindakan dan pelaksanaan tindakan.

Hasil observasi terhadap aktivitas peneliti pada siklus I pertemuan pertama terdapat beberapa aspek yang belum terlaksana yakni peneliti belum menarik perhatian peserta didik dalam pelaksanaan pembelajaran. Disamping itu peneliti pula belum menggunakan bahasa yang sederhana yang dapat dimengerti peserta didik sehingga peneliti harus menyesuaikan diri dengan tingkat kemampuan komunikasi peserta didik. Peneliti pula belum memusatkan perhatian yang lebih mendalam agar mereka lebih aktif dalam proses pembelajaran. Kemudian peneliti pula perlu menyesuaikan antara media pembelajaran yang digunakan dengan karakteristik peserta didik sebagai alat untuk menciptakan proses pembelajaran yang efektif, inovatif, kreatif dan menyenangkan. Dengan demikian persentase hasil observasi aktivitas peneliti pada siklus I pertemuan pertama hanya mencapai $45,83 \%$. Hal tersebut masih dianggap kurang karena semua aspek kegiatan pembelajaran belum terlaksana dengan baik.

\section{Hasil Observasi Aktivitas Peneliti Pada Siklus I Pertemuan Kedua}

Hasil observasi aktivitas peneliti pada siklus I pertemuan kedua yakni pembelajaran mulai berjalan dengan lancar dan sudah terorganisis dengan baik, hanya saja peneliti belum menggunakan bahasa yang sederhana yang dapat dimengerti oleh peserta didik kelas VIII 2 di SMP Negri 23 Konawe Selatan. Selain daripada itu, peneliti pula belum memusatkan perhatian yang lebih mendalam agar peserta didik lebih aktif dalam proses pembelajaran. Namun demikian pada siklus I pertemuan kedua persentase aktivitas peneliti mulai meningkat dari 45,83\% menjadi 51,04\% sehingga aktivitas peneliti pada siklus I pertemuan pertama dan pertemuan kedua mengalami peningkatan sebesar $5,21 \%$.

\section{Hasil Observasi Aktivitas Peserta Didik Siklus I Pertemuan Pertama}

Aktivitas peserta didik siklus I pertemuan pertama ditemukan bahwa dari 23 aspek yang diamati masih terdapat 7 aspek yang belum terlaksana yakni masih terdapat peserta didik yang belum menjawab apersepsi dari peneliti, belum memperhatikan penjelasan kompetensi yang ingin dicapai, belum memperhatikan penjelasan tujuan pembelajaran. Selain daripada itu sebagian peserta didik belum memahami aturan main metode pembelajaran snowball throwing, belum terbangun imajinasi dalam menggunakan bola salju, belum menggunakan waktu secara tepat sesuai dengan langkah-langkah model pembelajaran dan peserta didik masih terlihat gaduh saat pelaksanaan pembelajaran. Adapun hasil observasi aktivitas peserta didik pada silkus I pertemuan pertama sebesar $50 \%$. 


\section{Hasil Obsevasi Aktivitas Peserta Didik Siklus I Pertemuan Kedua}

Aktivitas peserta didik pada siklus I perteman kedua sudah berjalan dengan lancar dan cukup terorganisir. Peserta didik perhatiannya mulai berjalan dengan baik selama proses pembelajaran sesuai dengan langkah-langkah model pembelajaran snowball throwing. Dari 23 aspek yang diamati, masih terdapat 5 aspek yang belum terlaksana yakni peserta didik perhatiannya belum terpusat pada proses pelaksanaan pembelajaran, belum termotivasi untuk melaksanakan pembelajaran, belum menjawab aperepsi dari peneliti, belum mendengarkan tujuan pembelajaran yang disampaikan oleh peneliti, belum mendengarkan materi pokok yang disampaikan dan masih ada peserta didik yang gaduh saat pelaksanaan pembelajaran. Adapun hasil persentase aktivitas peserta didik pada siklus I pertemuan ke dua yakni sebesar 65,21\%. Dengan demikian dapat dikatakan bahwa aktivitas peserta didik pada siklus I pertemuan kedua belum maksimal karena masih ada beberapa aspek yang belum terlaksana.

\section{Refleksi dan Analisis}

Dalam kegiatan refleksi bersama observer pada tindakan siklus I ditemukan beberapa kekurangan yakni peneliti belum menarik perhatian peserta didik dalam proses pelaksanaan pembelajaran. Kemudian daripada itu peneliti pula belum menggunakan bahasa yang sederhana yang dapat dimengerti peserta didik sehingga peneliti harus menyesuaikan diri dengan tingkat kemampuan komunikasi peserta didik. Selanjutnya masih terdapat peserta didik yang belum menjawab apersepsi dari peneliti, belum memperhatikan penjelasan kompetensi yang ingin dicapai, belum memperhatikan penjelasan tujuan pembelajaran. Selain daripada itu sebagian peserta didik belum memahami aturan main metode pembelajaran snowball throwing, belum terbangun imajinasi dalam menggunakan bola salju, belum menggunakan waktu secara tepat sesuai dengan langkahlangkah model pembelajaran dan peserta didik masih terlihat gaduh saat pelaksanaan pembelajaran. Selain daripada itu, masih ada peserta didik yang perhatiannya belum terpusat pada proses pelaksanaan pembelajaran, masih terdapat pula beberapa peserta didik yang belum termotivasi untuk melaksanakan kegiatan pembelajaran dan belum mendengarkan pula materi pokok yang disampaikan oleh peneliti.

Setelah melakukan refleksi maka peneliti melaksanakan evaluasi dalam upaya untuk mengetahui keberhasilan tindakan siklus I melalui penerapan model pembelajaran snowball throwing. Evaluasi dilakukan melalui tes hasil belajar kepada peserta didik pada akhir siklus yakni pda tanggal 29 Februari 2020. Nilai hasil belajar peserta didik pada pelaksanaan siklus I yakni peserta didik yang mencapai nilai 70 ke atas dalam kategori tuntas sebanyak 11 orang sedangkan yang memperoleh nilai $70 \mathrm{ke}$ bawah dalam kategori tidak tuntas sebanyak 10 orang dengan persentase ketuntasan secara klasikal mencapai 52, $38 \%$ dan ratarata 63,80 . Peningkatan hasil belajar dari pra siklus ke siklus I adalah sebesar 23, 80 \%. Jika dibandingkan dengan tes awal maka terjadi peningkatan hasil belajar setelah pelaksanaan tindakan siklus I dengan menerapkan model pembelajaran snowball throwing.

Berdasarkan hasil kegiatan refleksi dan evaluasi yang dilakukan oleh peneliti, maka dapat dianalisis bahwa tindakan siklus I melalui penerapan model pembelajaran snowball throwing menunjukkan peningkatan, akan tetapi belum berhasil sesuai dengan indikator yang telah ditetapkan dalam penelitian tindakan kelas yakni $80 \%$ mencapai ketuntasan secara klasikal. Data hasil belajar peserta didik setelah pelaksanaan siklus I menunjukkan bahwa dari 21 peserta didik yang mengikuti tes, jumlah peserta didik yang memperoleh ketuntasan dengan nilai 70 ke atas sebanyak 11 orang sedangkan yang belum mencapai nilai 70 sebanyak 10 orang. Dengan demikian ketuntasan belajar secara klasikal hanya mencapai 52, 38\% dengan nilai rata-rata 63,80 . 


\section{Tindakan Siklus II}

Pada tindakan siklus I terdiri dari beberapa tahapan sebagai berikut :

\section{Perencanaan Tindakan}

Pada tahap perencanaan tindakan siklus II peneliti menganalisis rencana pelaksanaan pembelajaran , membuat lembar kerja siswa, membuat lembar observasi, menyiapkan media pembelajaran dan membuat soal untuk evaluasi hasil belajar.

\section{Pelaksanaan Tindakan Siklus II Pertemuan Pertama ( Sabtu, 7 Maret 2020)}

Pelaksanaan tindakan siklus II pertemuan pertama dengan materti pokok yakni tentang Munafiq. Pada kegiatan pendahuluan, peneliti memulai pembelajaran dengan ucapan salam, berdo'a, absensi, memberi motivasi, menyampaikan materi yang akan dibahas, menyampaikan tujuan pembelajaran dan melakukan apersepsi.

Pada kegiatan inti, peneliti membentuk kelompok-kelompok dan masing-masing ketua kelompok memberikan penjelasan materi, kemudian masing-masing ketua kelompok kembali ke kelompoknya untuk menjelaskan materi pembelajaran kepada teman kelompoknya. Setelah itu masingmasing peserta didik diberikan satu lembar kertas kerja untuk menuliskan satu pertanyaan yang menyangkut materi yang telah dijelaskan oleh ketua kelompok. Selanjutnya, kertas tersebut dibuat seperti bola dan dilempar dari satu peserta didik ke peserta didik yang lain selama kurang lebih 5 menit. Setelah peserta didik dapat satu bola atau satu pertanyaan, maka diberikan kesempatan kepada peserta didik untuk menjawab pertanyaan yang tertulis dalam kertas berbentuk bola tersebut secara bergantian. Setelah semuanya mendapat giliran, kemudian peneliti menyimpulkan materi pembelajaran.

Sedangkan pada kegiatan penutup, peneliti melakukan evaluasi dengan memberikan LKS kepada peserta didik. Peneliti pula memberikan pesan moral dan menutup pembelajaran dengan ucapan hamdallah secara bersama-sama.

Pelaksanaan Tindakan Siklus II Pertemuan
Kedua (Sabtu, 14 Maret 2020)

Pertemuan ke dua siklus I dengan materi pokok yakni tentang Munafiq. Kegiatan pembelajaran pada pertemuan ke dua siklus I ini sama halnya dengan pertemuan pertama siklus I.

Kegiatan awal pembelajaran dimulai dengan ucapan salam, berdo'a, absensi, memberi motivasi, menyampaikan materi yang akan dibahas, menyampaikan tujuan pembelajaran dan melakukan apersepsi.

Pada kegiatan inti, peneliti membentuk kelompok-kelompok dan masing-masing ketua kelompok memberikan penjelasan materi, kemudian masing-masing ketua kelompok kembali ke kelompoknya untuk menjelaskan materi pembelajaran kepada teman kelompoknya. Setelah itu masingmasing peserta didik diberikan satu lembar kertas kerja untuk menuliskan satu pertanyaan yang menyangkut materi yang telah dijelaskan oleh ketua kelompok. Selanjutnya kertas tersebut dibuat seperti bola dan dilempar dari satu peserta didik ke peserta didik yang lain selama kurang lebih 5 menit. Setelah peserta didik dapat satu bola atau satu pertanyaan maka diberikan kesempatan kepada peserta didik untuk menjawab pertanyaan yang tertulis dalam kertas berbentuk bola tersebut secara bergantian. Setelah semuanya mendapat giliran, kemudian peneliti menyimpulkan materi pembelajaran.

Sedangkan pada kegiatan penutup, peneliti melakukan evaluasi dengan memberikan LKS kepada peserta didik. Peneliti pula memberikan pesan moral dan menutup pembelajaran dengan ucapan hamdallah secara bersama-sama.

\section{Observasi}

Observasi dilaksanakan untuk mengamati pelaksanaan tindakan pembelajaran di kelas sesuai dengan model pembelajaran snowball throwing. Aspek-aspek yang diamati dalam kegiatan observasi meliputi aktivitas peneliti dan peserta didik selama pelaksanaan proses pembelajaran. Observasi ini dilakukan oleh observer yakni guru mata pelajaran dan peneliti lainnya sejak tindakan dimulai yakni dari awal berlangsungnya proses pembelajaran sampai 
berakhirnya pelaksanaan pembelajaran dengan menggunakan lembar observasi aktivitas peneliti dan peserta didik. Observasi bertujuan untuk mengetahui aktivitas peneliti dan peserta didik setelah tindakan siklus I ke siklus II apakah meningkat atau sama saja atau justru tambah menurun.

\section{Hasil Observasi Aktivitas Peneliti Siklus II Pertemuan Pertama}

Hasil observasi aktivitas peneliti siklus II pertemuan pertama menunjukkan bahwa secara umum mampu melaksanakan langkah-langkah pembelajaran dengan baik. Namun demikian, masih terdapat 2 aspek yang tidak terlaksana yakni peneliti belum menggunakan bahasa yang sederhana dan peneliti belum memusatkan perhatian peserta didik saat pelaksanaan pembelajaran. Adapun hasil observasi aktivitas peneliti siklus II pertemuan pertama yakni $79,16 \%$.

\section{Hasil Observasi Aktivitas Peneliti Siklus II Pertemuan Kedua}

Hasil observasi aktivitas peneliti siklus II pertemuan kedua sudah berjalan dengan baik dan terorganisir yakni semuanya telah terlaksana dengan baik. Hal tersebut berarti peneliti sudah melaksanakan kegiatan pembelajaran sesuai dengan langkah-angkah model pembelajaran snowball throwing. Adapun hasil observasi aktivitas peneliti siklus II pertemuan kedua yakni $82,29 \%$.

Berdasarkan kenyataan tersebut di atas, menunjukkan bahwa aktivitas peneliti dalam setiap siklus selalu mengalami peningkatan. Dengan demikian dapat disimpulkan bahwa persentase aktivitas peneliti pada siklus I pertemuan pertama sebesar $45,83 \%$ dan pertemuan kedua mencapai $51,04 \%$. Sedangkan pada siklus II pertemuan pertama meningkat menjadi $79,16 \%$ sedangkan pada pertemuan kedua mengalami peningkatan sebasar 82,29\%.

\section{Hasil Observasi Aktivitas Peserta Didik Siklus II Pertemuan Pertama}

Hasil observasi terhadap aktivitas peserta didik siklus II pertemuan pertama mencapai $86,95 \%$. Hal ini sudah cukup maksimal meskipun masih ada beberapa aspek yang yang belum terlaksana dengan baik seperti masih kurang menjawab pertanyaan dalam apersepsi dari peneliti dan belum mendengarkan penjelasan tujuan pembelajaran yang ingin dicapai.

\section{Hasil Observasi Aktivitas Peserta Didik Siklus II Pertemuan Kedua}

Adapun hasil observasi peserta didik siklus II pertemuan kedua adalah 95,65\%. Hal ini sudah cukup maksimal karena hampir semua aspek sudah berjalan dengan sangat baik. Dengan demikian, persentase setiap siklus mengalami peningkatan. Hasil aktivitas peserta didik siklus I pertemuan pertama mencapai 50\%, sedangkan pada pertemuan kedua mencapai $65,21 \%$. Pada siklus ke II pertemuan pertama meningkat menjadi $86,95 \%$ dan pada pertemuan kedua meningkat sebesar 95, 65\%.

\section{Refleksi dan Analisis}

Hasil belajar peserta didik siklus II menunjukkan peningkatan yang cukup memuaskan. Penelitian tindakan kelas dikatakan berhasil karena telah mencapai indikator keberhasilan yang menjadi acuan dalam penelitian tindakan kelas yakni peserta didik yang memperoleh nilai KKM 70 ke atas mencapai $80 \%$. Dengan demikian, penelitian ini tidak perlu dilanjutkan lagi pada siklus berikutnya karena sudah mencapai target yang telah ditentukan.

Evaluasi pada siklus II dengan memberikan tes hasil belajar. Dari 21 peserta didik yang mengikuti evaluasi, 17 orang telah mencapai ketuntasan dan tinggal 4 orang yang belum mencapai ketuntasan. Dengan demikian, maka diperoleh persentase ketuntasan belajar sebesar 80, 90\% dengan nilai rata-rata 71,90. Hal tersebut menunjukkan bahwa penerapan model pembelajaran snowball throwing dapat meningkatkan hasil belajar peserta didik kelas VIII 2 di SMP Negeri 23 Konawe Selatan.

Penelitian tentang model pembelajaran snowball throwing pernah dilakukan oleh Emah Hujaemah DKK, dengan judul penelitian: Pengaruh Penerapan Model Snowball Throwing 
terhadap hasil belajar IPA di Sekolah Dasar (Jurnal Literasi, Vol. 5, No. 1, Oktober 2019). Berdasarkan hasil perhitungan uji t, diperoleh bahwa terdapat perbedaan yang cukup berarti antara kedua data pretest dan postest. Hasil t hitung sebesar 26,2 lebih besar dari t table sebesar 1,72 sehingga hasil penelitian dapat menjawab hipotesis yang menunjukkan adanya pengaruh model pembelajaran snowball throwing terhadap hasil belajar IPA. Penelitian serupa juga dilakukan oleh Ira Mardiana dan Muhammad Syazali dengan judul penelitian : Implementasi Model Pembelajaran Kooperatif Tipe Snowball Throwing untuk Meningkatkan Hasil Belajar IPA (Jurnal Literasi, Vol. 15, No. 1, Januari 2020). Berdasarkan analisis diskriptif menunjukkan bahwa hasil belajar peserta didik pada siklus I ke siklus II mengalami peningkatan. Skor rata-rata hasil belajar $(\mathrm{R})=78 \%$, daya serap $(\mathrm{SD})=78,33 \%$ dan ketuntasan belajar $(\mathrm{KB})=$ $85,71 \%$. Dari kondisi ini diperoleh bahwa skor rata-rata kelas, daya serap dan ketuntasan belajar pada siklus II meningkat sebesar 5\%.

\section{KESIMPULAN}

Berdasarkan hasil penelitian dan pembahasan yang telah diuraikan sebelumnya, maka dapat disimpulkan bahwa penerapan model pembelajaran snowball throwing dapat meningkatan hasil belajar peserta didik kelas VIII 2 di SMP Negeri 23 Konawe Selatan. Hal tersebut dapat dilihat dari hasil tes sebelum prasiklus yakni $23,80 \%$ dengan nilai rata-rata 59,14 . Setelah pelaksanaan siklus I, persentase ketuntasan belajar mencapai 52,38\% dengan nilai rata-rata 63,80 . Kemudian pada siklus II, persentase ketuntasan belajar mencapai $80,95 \%$ dengan nilai rata-rata 71,90. Adapun peningkatan hasil belajar dari prasiklus ke siklus I sebesar 28,58\% sedangkan peningkatan dari siklus I ke siklus II sebesar 22,21\% dan peningkatan dari pra siklus ke siklus II sebesar $57,15 \%$.

\section{DAFTAR PUSTAKA}

Arikunto, Suharsimi, 2015, Penelitian Tindakan Kelas, Jakarta: Bumi Aksara.

Depdiknas, 2003, Undang-Undang Sistem Pendidikan Nasional, Jakarta : Sinar Grafika.

Ekawana, 2009, Penelitian Tindakan Kelas, Jakarta : GP Press.

Hamalik, Oemar, 2011 Proses Belajar Mengajar, Jakarta : Bumi Aksara.

Hamdayana, 2014, Model dan Metode Pembelajaran Kreatif dan Berkarakter, Bogor, Ghalia Indonesia.

Hujaemah, Emah dkk, Pengaruh Penerapan Model Snowball Throwing terhadap hasil belajar IPA di Sekolah Dasar Jurnal Literasi, Vol. 5, No. 1, (2019).

Kurniasih 2016, Ragam Pengembangan Model Pembelajaran, Jakarta : Kata Pena.

Mardiana, Ira dan Muhammad Syazali Implementasi Model Pembelajaran Kooperatif Tipe Snowball Throwing untuk Meningkatkan Hasil Belajar IPA, Jurnal Literasi, Vol. 15, No. 1, (2020).

Ngalimun, 2012, Strategi dan Model Pembelajaran, Yogyakarta : Aswaja Persindo.

Sanjaya, Wina, Strategi Belajar Mengajar, Jakarta: Cet 12, Prenada Media, 2016

Tri Setiawati,Yuyun, Penerapan Model Pembelajaran Snowball Trowing dalam Meningkatkan Motivasi dan Hasil Belajar Siswa, Jurnal Ilmiah FKIP Univ Subang, Vol. 3, No. 1, (2017). 